\title{
(11) Nordregio
}

\section{Sámi Youth Perspectives, Education and the Labour Market}

Lise Smed Olsen, Linnea Löfving, Juho-Matti Paavola, Jens Bjørn Grelck

NORDREGIO REPORT 2020:5 
Sámi Youth Perspectives, Education and the Labour Market

Lise Smed Olsen, Linnea Löfving, Juho-Matti Paavola, Jens Bjørn Grelck

NORDREGIO REPORT 2020:5 


\section{Table of Contents}

ISBN 978-91-87295-93-5 (PDF)

ISSN 1403-2503

DOI: http://doi.org/10.6027/R2020:5.1403-2503

๑) Nordregio 2020

Nordregio

P.O. Box 1658

SE-111 86 Stockholm, Swede

nordregio@nordregio.org

www norden.org

Authors: Lise Smed Olsen, Linnea Löfving, Juho-Matti Paavola, Jens Bjørn Grelck Cover photo: Michal Janek (Unsplash)

Nordregio

is a leading Nordic and European research centre for regional development and planning, established by the Nordic Council of Ministers in 1997. We conduct solution-oriented and applied research, addressing current issues
from both a research perspective and the viewpoint of policymakers and practitioners. Operating at the international, national, regional and loca levels, Nordregio's research covers a wide geographic scope, with an

emphasis on the Nordic and Baltic Sea Regions, Europe and the Arctic.

The Nordic co-operation

Nordic co-operation is one of the world's most extensive forms of regional Faroe Islands, Greenland, and Ark, Finland, Iceland, Norway, Sweden, and the in politics, the economy, and culture. It plays an important role in European and international collaboration, and aims at creating a strong Nordic community in a strong Europe. Nordic co-operation seeks to safeguard Nordic and regional interests and principles in the global community. Common Nordic values help the region solidify its position as one of the world's mos

\section{The Nordic Council of Ministers}

is a forum of co-operation between the Nordic governments. The Nordic have the overall responsibility. Its activities are co-ordinated by ministers ministers for co-operation, the Nordic Committee for co-operation and portfolio ministers. Founded in 1971

The Nordic Council

is a forum for co-operation between the Nordic parliaments and governments. The Council consists of 87 parliamentarians from the Nordic co-opestion. Founded in 1952 ?
1. Introduction

1.1 Purpose of the study

1.2 Structure of the report

2. Overview of Sámi Institutions and Organisations

2.1 Sámi parliaments: education and regional development.

eristion...........

.

Carliaments..................................................................13

2.2. Sámi Youth Associations ............13

2.3 Sámi Education Institutions and Programmes................................................................. 15

2.3.1 Upper Secondary Education .................................................................................................... 18

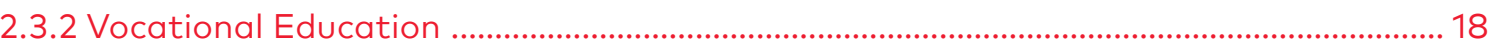

2.3.3 Higher Education

19

3 Analysis: Youth Perspectives, Education and Labour Market..........................21

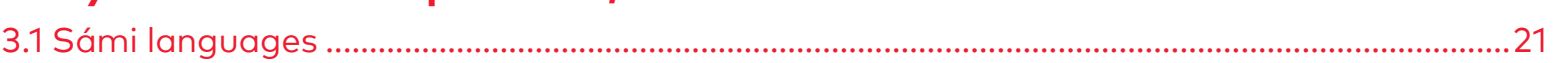

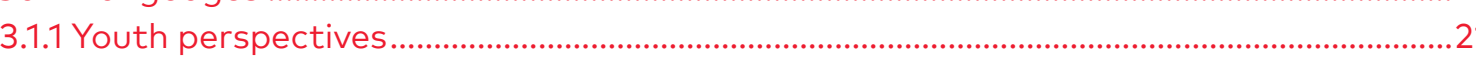

3.1.2 Challenges and opportunities: education and labour market ...........................................21

3.1.3 Sámi teacher training: a political focus ..............................................................................21

3.2 Healthcare

3.2.1 Youth perspectives

3.2.1 Challenges and opportunities: education and labour market .......................................22

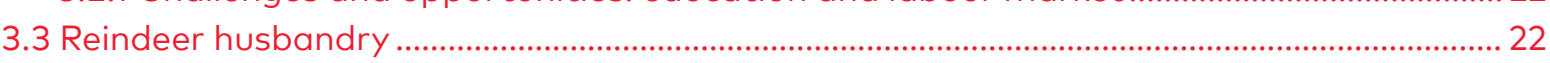

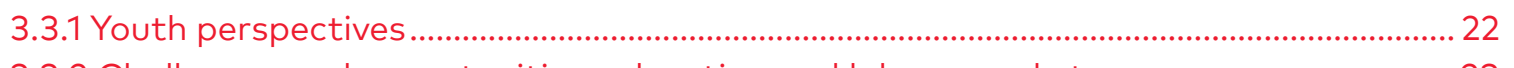

3.3.2 Challenges and opportunities: education and labour market ..........................................23

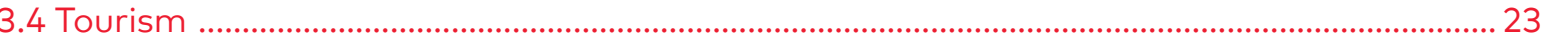

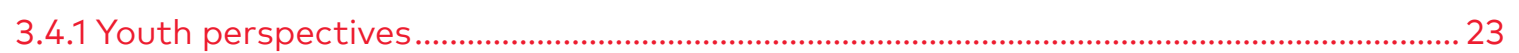

3.4.2 Challenges and opportunities: education and labour market .......................................2 24

3.5 Sámi handicrafts (duodji) ......................................................................................................... 24

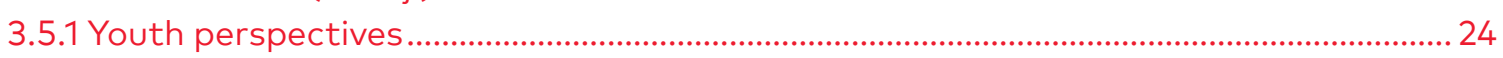

3.5.2 Challenges and opportunities: education and labour market ......................................2

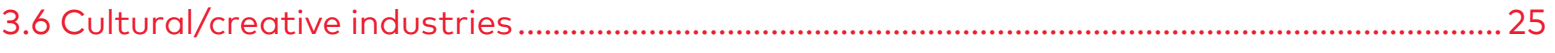

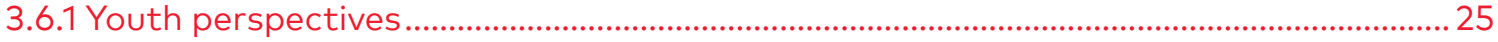

3.6.2 Challenges and opportunities: education and labour market .........................................2

4. Conclusions

4.1 Sámi language skills provide a strong basis for strengthening self-confidence,

cultural identity and job opportunities ...

4.2 Sámi-related jobs and new regional development opportunities ............................................ 27

4.3 Challenges and opportunities for cross-border cooperation ………………………………........2.

5. Method and list of interviewees 


\section{Introduction}

The Thematic Group on Sustainable Rural Development has been established to support the implementation of the Nordic Co-operation Programme for Regional Development and Planning 20172020. One of the objectives of the Programme is to contribute to the development of policies and new solutions in relation to the challenges that Nordic countries face regarding sustainable rural development. Among other initiatives, the The matic Group on Sustainable Rural Development has decided to follow up on the OECD Rural Policy Review, Linking the Indigenous Sámi People with Regional Development in Sweden (published in 2019) by focussing on Sámi youth. This is because the Review did not pay specific attention to Sámi youth. However, it did highlight that young women, especially, are leaving traditional Sámi occupations. The OECD also recommends that Sámi youth associations, such as Sáminuorra, should be included in discussions on Sámi economic development in regional development policy.'

The OECD highlights Sámi economic development opportunities, which are relevant not only in Sweden, but also in Norway and Finland. They involve reindeer husbandry, tourism, the cultura sector and other rural activities, as follows:

- The Sámi reindeer industry is seeing a sinificant growth in demand. But while there are growth opportunities for this industry, it is also limited by such factors as reindeer predators, climate change and competing land uses (e.g. mining).

- The unique culture and traditions of the Sámi people are an important feature in regional tourism strategies. However, there are very few Sámi entrepreneurs presently engaged in offering services to tourists. A growing nature based tourism sector - with activites such as hunting, fishing, skiing, snowmobiling and dog-sledding - has the

potential to create new sources of income and future employment opportunities for the Sámi.

- Sámi food production and duodji (handicrafts) also show potential for growth. At present, the Sámi cultural sector is relatively small. Prospects for the commercialisation for this sector differ, and it may require either seed capital or grants in order to thrive.

Many Sámi businesses draw on traditional knowledge in the management of the landscape and in the production of goods and services. Sám businesses tend to balance market participation with non-market values, stressing the importance of sustaining culture over time.

'Sápmi' is the name of the geographical area traditionally inhabited by the Sámi people (marked by the dark red line on the map). The size of Sámi population is estimated to be around 80 00O, spread over four countries. There are approximately 20,000 Sámi people in Sweden, 50,000 Norway, 8,000 in Finland and 2,000 in Russia ${ }^{3}$ A significent number of Sami people now lve in the Ianfican numbr of Sami peole now tive in the larger cities of these respective countries. The bigger Nordic cities within Sápmi containing a notable Sámi population include Vadsø, Alta, Troms Harstad, Bodø, Trondheim, Kiruna, Gällivare and Ostersund. Other larger Nordic cities with a significant Sámi population beyond Sápmi are Oslo, Luleå, Piteå, Umeå, Uppsala, Stockholm, Rovaniemi, Oulu and Helsinki.

The Sámi people living in the Nordic countries have been recognised as being in an atypical situation compared to other indigenous peoples around the world, because their socioeconomic status is comparable with the national averages. This also means that the Sami population in the Nordic countries has the same access to education and career pathways as the majority population.

OECD (2019), 'Linking the Indigenous Sámi People with Regional Development in Sweden', OECD Rural Policy Reviews, OECD Publishing, Paris, p.125.

${ }_{2}^{2}$ Ibid. P.13.
${ }_{3}^{3}$ This estimation

the 2010 census in Russia.

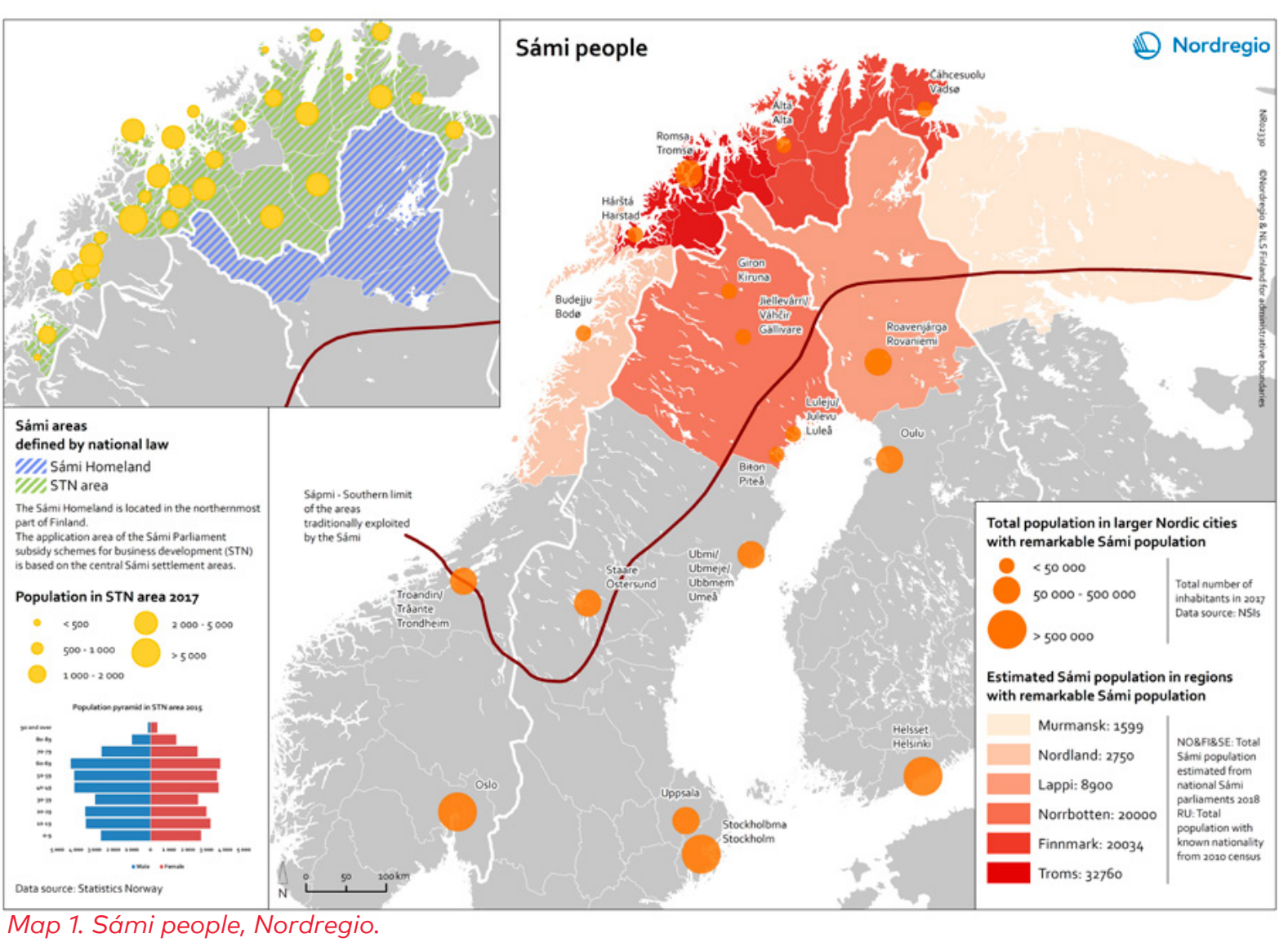

Today, most Sámi people live outside Sápmi, and many do not speak the Sámi languages, bear visible cultural traits, or possess knowledge that is traditionally connected to 'Sáminess'. Many have a mixed ethnic background. Only a minority of the Sámi people have reindeer husbandry as their main occupation. The question of who is Sámi has been noted to be primarily one of self-identity That is, tho be primarily one of self-identity. are Sámi peopar . Because of the bicultural reality of many therefore thaldifference in their livelihoods, it is one stakeholder group. ${ }^{4}$ This is a specific point in the study where there is reference to Sámi youth having direct links to the traditional Sámi occupation of reinder herding, as well as young people who have grown up outside the Sami-spe

The OECD Rural Policy Review highlights the role of education and training in supporting growth opportunities for Sámi businesses (and for northern Sweden more generally) in such ar- eas as tourism, cultural industries and food production. Sámi educational institutions have been established in the Norwegian, Swedish and Finnish parts of Sápmi. These institutions may be seen to play an important role in sustaining culture over time, and in preparing Sámi young people for their working life.

\subsection{Purpose of the Study}

This study aims to provide an overview and knowledge of Sámi educational institutions and Sám youth perspectives, which can feed into the development of regional development initiatives and policies. The study therefore brings together insights into the links between Sámi education institutions and the labour market, plus the perspectives of Sámi young people on their participation in world of work. Our focus on youth also includes providing an ouervew of which topics Scmi youth organisations engage with, and how they are involved in regional development. The study
also considers both similarities and differences you h orgaisations engage with, and how they 
and across Sápmi and highlights forms of crossborder cooperation which are in place today, as well as the potential for future forms.

Our analysis addresses the following questions:

1. What perspectives do Sámi young people have on labour market opportunities and regional economic development?

2. How do Sámi educational institutions design educational programmes which foster the connection between the Sámi indigenous culture and regional economic development?

Sustainable development perspectives on the vironment (e. land use), gender (e. that outward migration is primarily by women), and culture wand econ and economic developent (eg. how young Sámi percevive tradtionalcontempory Sami culture part of the analysis.

\subsection{Structure of the report}

Chapter 2 provides an overview. It introduces the respective Sámi parliaments' focus on education and business development policy. It then provides an overview of the organisation, and specific areas of concern, of Sámi youth organisations - including the youth parliaments attached to the Sám
Parliaments, and Sámi youth associations. Finally, it provides an overview of Sámi educational institutions at upper secondary, vocational and higher education levels.

Chapter 3 provides an analysis of links between Sámi youth perspectives and educationa opportunities. This has been structured according to the vocational areas highlighted in the OECD Review (reindeer husbandry, tourism, Sámi handicrafts, and cultural industries). It also covers the issue of languages, Sámi teachers and Sámi healthcare, which are all political priorities in educational institutions and among Sámi young people themselves.

Chapter 4 presents conclusions from our analcooperation.

Finally, chapter 5 describes the methods employed in this study, plus an overview of the Sámi stakeholders interviewed for it. In terms of stakeholder involvement, the data acquisition was somewhat limited, due to a lack of direct participation by Sámi youth associations and Sámi educational institutions in Finland. This entailed greater reliance on desk research and on interviews with the Sámi Parliament and youth representatives in Finland on issues related to education.

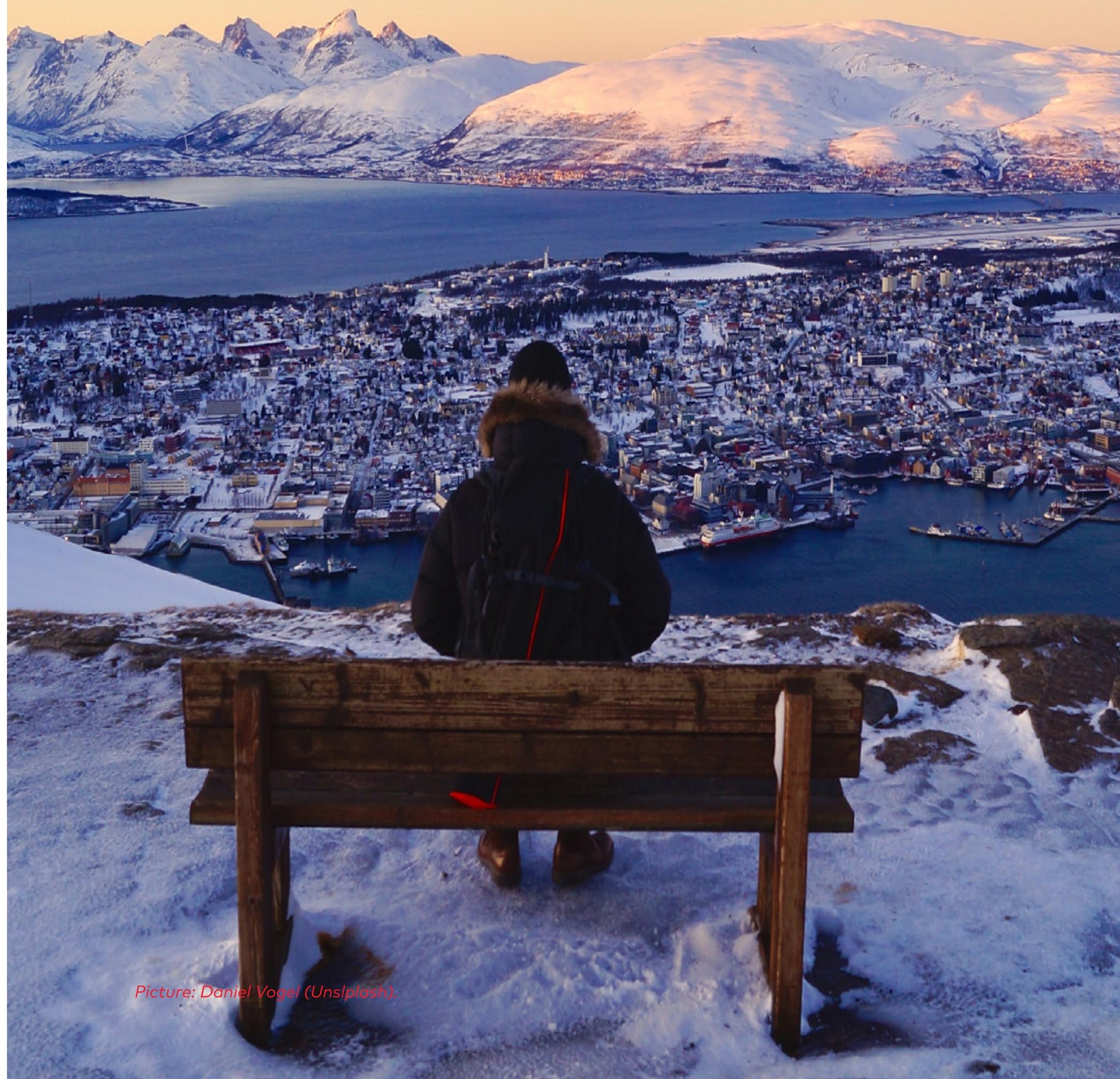




\section{Overview of Sámi Institutions and Organisations}

In order to provide a contextual background for our overall analysis, this chapter outlines the responsibilities and initiatives of the different Sámi parliaments in the areas of education and business development, along with the areas that interest Sámi youth organisations, and the structure and principal concerns of Sámi educationalinstitutions across Sápmi.

\subsection{Sámi parliaments: education and}

\section{regional development}

The Sámi parliaments are democratically elected institutions that represent Sámi political interests both nationally and internationally. In Sweden, the Sámi Parliament is also a national state agency. Their overall aim is to ensure Sámi autonomy and self-government in matters relating to internal affairs, including their own economic, social and cultural development. The constitutions and laws of Finland, Norway and Sweden recognise Sámi rights in different ways. While Sámi parliaments exist in all three states, their rols and responsibilties differ (as per the text box next page).

Education and business development are policy areas in which there are differences between the mandates of the respective Sámi parliaments.

In Finland, the main responsibilities of the Sámi Parliament involve language and education. It is their responsibility to produce teaching material for Sámi-related courses at both primary and upper secondary school levels. The Sámi Parliament in Finland does not have funds at its disposal to allocate to Sámi business development projects.
In Norway, the Sámi Parliament is also responsible for developing the curriculum and for producing teaching materials for Sámi-related courses at primary and upper secondary school levels. The Sámi Parliament continually monitors the need for education and research, and it can bring influence council levels when particular needs are observed for Sámi education within society as a whole. Curfor Sámieducation within society as a whole. Current discussions with reg soclety as a whole. Curthe identified need for Sámi knowledge and language skills among nurses and police officers. I cation, the Sámi Parliament also offers scholarships to encourage further training in these fields. The Sámi Parliament in Norway can also allocate grants to business development projects.

In Sweden, the Sámi Parliament does not have the mandate to work on education policy, and thus it is not involved in the development of school curricula. However, as mentioned above, the Sámi Parliament does have indirect influence on Sámi Painal matters through Same Education Bodd The Sami Parland the Same Education Bocrd The Simi Parlament can support business development projects financially, within the framework of the EU Rural Develop ment Programme. In Sweden the Sámi Parliament has a strong focus on traditional Sámi industries/ sectors, such as reindeer husbandry and duodji, but also fisheries, food processing and tourism. One significant role of the Sámi Parliament in Sweden is in facilitating Sámi people working in traditional sectors, with the aim of making visible, and diversifying, Sámi culture. to bear at the national government and county the fields of teacher education and language edu-
Sámi political institutions and legal frameworks in Finland

Norway and Sweden 5

\section{Finland}

Sámi rights in Finland are defined around geographic parameters. They therefore apply only to the three northernmost municipalitie in Finland (Enontekiö, Inari and Utsjoki) and to the Sámi reindeer-herding district of Lapin Paliskunta in the municipality of Sodankylä. Under the Sámi Parliament Act, the relevant Parliament (established in 1996) with the opportunity to be heard, and to negotiate on, any specific questions falling within the scope of Section 9 of the aforementioned. In practical terms, the Sámi Parliament in Finland remains an advisory body with limited authority and decision-making power. Its political activities are also restricted by budgetary constraints.

\section{Norway}

Norway has constitutional guarantees fo Sámi rights, and the state is obliged to create the conditions ntate is obliged to creprotect and develop their own langugas their d their society. The Scimi Parliament (established in 1989) is regarded as an important part of the implementation of these ights, and its mandate includes all questions relating to the Sámi. It has the authority to make decisions when these concerns follow from legislative or administrative provisions. Jowever the Sómi Parliament is formally stil an advisory body, with limited decision-making powers.

Norway has an administrative area for the Sámi language (applying to 12 municipalities where the Sámi and Norwegian languages have equal status as national languages. The 2005 Finnmark Act recognises that the Sámi have ownership and rights to lands in Finnmark County. Around 95\% of the land in Finnmark County (about $46000 \mathrm{~km} 2$ an area approximately the size of Denmark) has been ransferred from state ownership to a new ntity called the Finnmark Estate - a joint body of the Sámi Parliament and the County Council of Finnmark. The Act contributes to e implementation of the natural resources dimension of Sámi self-determination. The tatus of Sámi rights to land in other counties remains unresolved.

\section{Sweden}

Like Finland and Norway, the Swedish nation Parliament has adopted a Sami Parliament Act which provides for the establishment of the Sámi Parliament. The Sámi Parliament is tasked by the Act with promoting a dynamic Sámi culture, and is mandated to make decisions about the distribution of state funds from the Sami Foundation Board, and to oth tre funds that are placed at the collective disposal of the Sámi.

The Sami Parliament is also mandated to appoint the board for the state agency known as the Same Education Board, direct Sami linguistic work, participate in social planning and ensure Sámi interests and needs are taken into consideration - including reindeer husbandry interests in the use of land and water. The Sami Parliament has funds from the EU Rural Development Programme in order to support business development projects. In a way that is different to Finland and Norway, the Sami Parliament in Sweden is both an elected body and a state authority focused on administrative task. Sweden's Sámi Parliament describes itself as "an advisory board with expertise on Sami issues". In 1977 the Swedish Parliament recognised the Sámi as an indigenous people. In 2011, the Swedish Constituto was ámi to the Sámi people. The Constitution stipulates that opportunities for the Sami people ife of the and develop a cultural and social Ife of their own shall be promoted. Interpretation of higenous rights in Sweden largely and fishing if a mer reindeer herding, hunting and regarding nation ma sami cooperative and, regarding national minority rights, access language. 
2.1.1 Cross-border cooperation on language standardisation

Cross-border cooperation between the Sámi Parliaments is organised through the Sámi Parliamentary Council, which operates as an umbrella organisation for collaboration. It is comprised of 21 members, appointed by the respective Sámi parliaments. The Sámi in Russia have observer status in the Sámi Parliamentary Council, because they do not have their own parliament.

Attempts have been made to strengthen cross-border cooperation on education through the Sámi Parliamentary Council but these have been challenged by national curriculum requirebeen che Panliam ments ali by differences in the curiculum requre- which lia for use across borders, for example. Lanmaterial for use across borders, for example. Languages is another related field which the Sámi Parliamentary Council has focused on. Two initiatives were particularly highlighted by interviewees, namely cooperation on Sámi language standardisation and the working group on 'Sámi Teaching Without Borders'.
In the period from 2015 to 2018, the Sámi parliaments in Sweden, Finland and Norway cooperated on the Giellagáldu project, aimed at safeguarding, promoting and strengthening the use of Sámi languages. This project was co-funded by the EU Interreg Nord programme. To achieve its goals, the project supported the development of the Nordic Resource Centre for Sámi Languages. As a professional expert body, the Centre's task is to create new terminology and standardise the Sámi languages. It advises on the use of names and offers consultation services to users of Sámi languages. Language experts were responsible for delivering practical language work as part of the project, and for dealing with issues a part of the proj to the languas in which they arising relatThe project delives in which they were working. The project delivered the first real-time consultation service dedicated to users of the various Sámi languages. It brought together the Giellatekno Centre for Saami Language Technology at the UiT (the Arctic University of Norway) and the Divvun group, which produces language-learning technologies for Sámi languages. Together they ensured

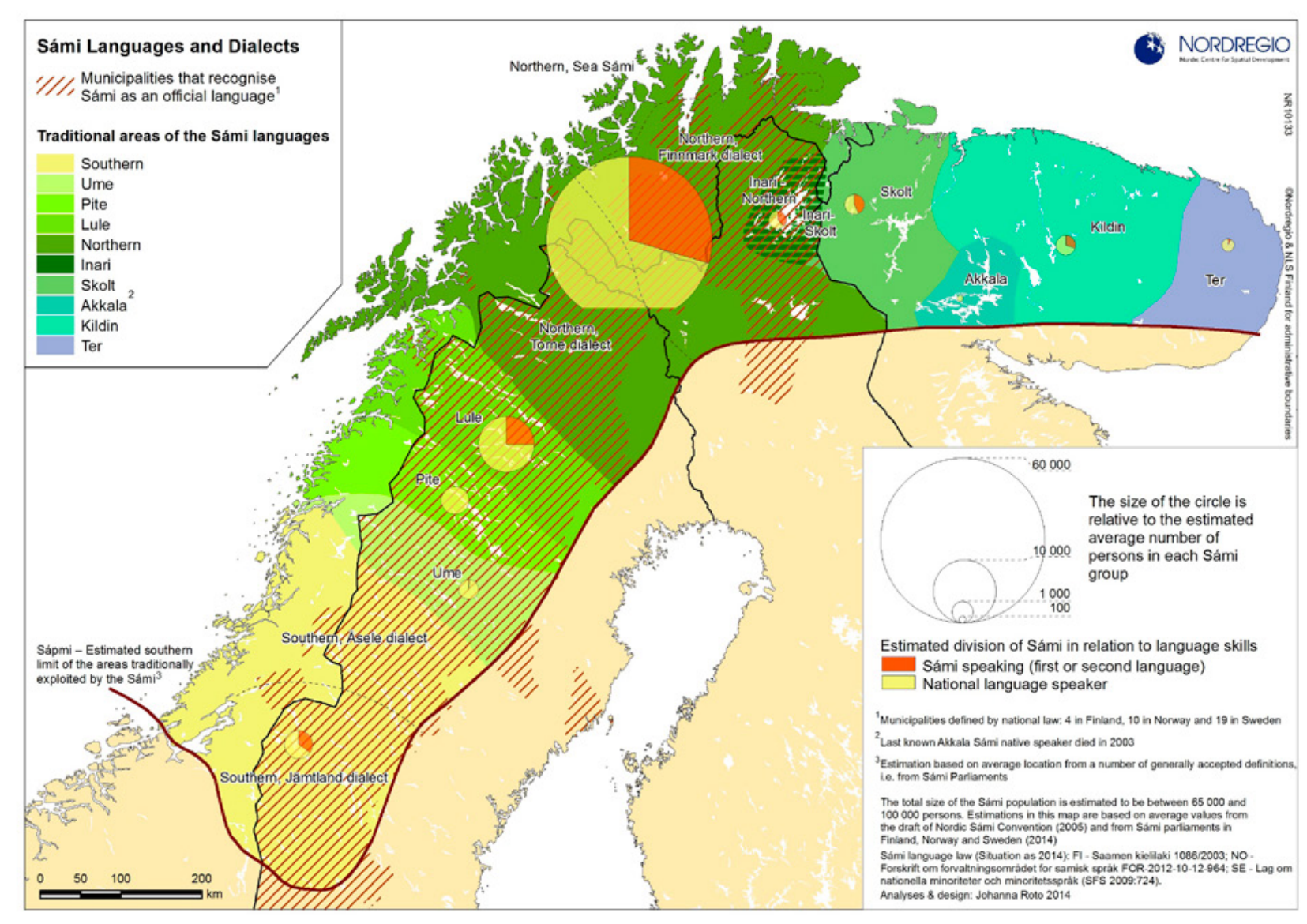

Map 2. Sámi languages and dialects, Nordregio.

that the standardisations and new terminologies were incorporated into practical language tools, such as proofing systems, spell-checking programmes, web dictionaries, and machine translation software. ${ }^{6}$

The map provides an overview of the trad tional catchment areas for the various Sámi languages. It also provides estimates of the number of Sámi people, and the proportion of those people who speak each of the Sámi languages. It should be noted that the map was produced in 2014. It indicates that North Sámi is the largest language group with most speakers, followed by Lule and Southern Sámi.

Starting in 2020, it has been decided that the Centre will fous on maistaining language standardisation of the North Sámi langugge. This is the ardisution of the Noth Sami la gur countries involved. The secretariat for longuas standardisutiod. The secretariat for language standardisation is based at the Sámi Parliament in Norway. Through this cooperation, which was first developed through the Interreg project, the Sámi parliaments in Norway and Finland, in dialogue with the Swedish National Agency for Education, will ensure that teaching material is developed according to the same language standard across borders. ${ }^{7}$

At the end of 2019, the working group on 'Sámi Teaching Without Borders' published a report with recommendations on how the Sámi parliaments of Norway and Finland and the boards of the Sámi schools in Sweden, can work more closely together on a more coherent Sámi education system. This also includes the ambition of promoting cooperation on reindeer husbandry education between upper-secondary and vocational schools and exploring approaches to utilising opportunities for distance learning across borders. This work was funded by the Sámi Parliament in Norway.

\subsection{Sámi youth organisations: issues}

\section{on the agenda}

Sámi parliaments, and to some extent regional development partnership forums in Sápmi, consult with Sámi young people ment youth councils and Sámi youth associations.

2.2.1 Youth Councils of the Sámi Parliaments Each of the Sámi parliaments have youth councils in place, with five members who are each appoint- ed for two-year terms. These youth councils are included as consultation partners on matters that concern young people in the Sámi Parliaments, and they also play a role in preparing statements and comments on behalf of Sámi young people on issues raised in the Sámi Parliaments. With some variation between them, the main functions of the Sámi youth councils are to:

Strengthen the influence of Sámi youth in Sámi parliaments.

Promote greater participation by young people in Sámi Parliament elections.

- Organise meeting places/events for Sámi youth.

The youth councils have separate budgets to develop projects, including the organising of events. Sámi youth councils also work together across borders as a sub-unit of the Sámi Parliamentary Council. In their respective countries, they also cooperate with (non-party political) Sámi youth associations. As it is the case with the Sámi Parliamentary Council, the chairing of the youth division rotates every four years. During this time, at least one event will be organised to bring together young Sámi across borders.

\subsubsection{Sámi Youth Associations}

Sámi youth associations are in place in Norway, Sweden and Finland, respectively. Sáminuorra, in Sweden, founded more than 50 years ago, has existed the longest, while Suoma Sámi Nuorat, in Finland, has existed for nearly three decades. Noereh, in Norway, has existed since 2009. Of the three, Sáminuorra has the strongest foundation, built up over a longer time period, in terms of the number of members and the degree of support offered to members. However, the associations in Norway and Sweden are organised in similar ways and have similar activities. So:

- They have branches in different parts of their countries.

- They organise an annual meeting that aims to bring together as many Sámi young people as possible.

- They are present and visible through activities at annual Sámi events.

- They are managed by their board members, un projects/activities aimed at promoting awareness of Sámi culture, and work to count er discrimination within the wider society. 
The three associations refer to themselves as sister organisations, but in practice there is limited cooperation between them. This is not due to lack of interest, but rather to a lack of resources. Land use issues, languages, and joint events are examples of issues upon which youth association representatives find opportunities for more cooperation across borders. Stakeholders from the different associations have also expressed interest in connecting and cooperating more with Sámi young people in Russia.

\section{Suoma Sámi Nuorat, Finland}

Suoma Sámi Nuorat, in Finland, was founded in 1991. The association works to strengthen the cultural identity of Sámi young people in Finland. It does this by organising cultural events, taking part in political discussions, and by functioning as a forum through which Sámi youth can network with each other, as well as internationally. Unfortunate$l y$, it was not possible to secure an interview with a representative from the association in Finland. Therefore, we cannot give a more detailed account of its operations. However, based on interviews with associations in Norway and Sweden, it is clear that Suoma Sámi Nuorat carries out similar activities to its sister organisations.

\section{Noereh, Norway}

ciation in Norway, Noereh, was established in 2009. It was based on the need to have a youth organisation that was independent of political or business interests. By the end of 2019, Noereh had 140 members. The purpose of the association is to provide a meeting place for young Sami and to be a dialogue partner for external agencies and individuals. The association is funded by an annual grant from the Sámi Parliament and membership fees. Noereh also regularly applies for project funding. That is, they organise events for which they apply for grants from the Sámi Parliament and from the county councils (fylkeskommuner). The associacounty councils (fylki Parliament and from the tion Ávjova board, and three local branches based in Avjovarrii (Kautoke

One of the key activities in Noereh is an annual meeting where the association gathers as many Sámi young people as possible. This rotates between the three local branches each year. The meeting typically attracts around 40 to 50 participants from all parts of the country. However, there are generally more participants from outside the Ávjovárri area. The branches in Tromsø and Oslo also organise more events and meetings locally than is the case in the Ávjovárri area. The proximity to other Sámi in the Avjovárri area means the young Sámi living have less need to gather at a conference and join the association. There are different workshops and issues on the agenda at the annual meeting - for example, ones related to reindeer herding and Sámi handicrafts. There is usually also a presentation by a representative of the Sámi Parliament. While Noereh is not party political, it encourages greater participation in politics by Sámi young people.

One of Noereh's priorities is to be represented and visible at the two annual Sámi festivals in Norway, which take place in Márkomeannu and Riddu Riđđu. The association works closely with these festivals, which means that its members are entitled to discounted tickets. The local branch for the Ávjovárri area also organises activities to coincide with the annual Easter festival, which is another annual Sámi event/festival. Noereh has also taken the initiative to promote the international day for traditional Sámi dress, when Sámi young people are encouraged to wear their Sámi dress to school or work. International Sámi Dress Day is followed up by a campaign on social media, in which young Sámi post photos using hashtags in wh from Noreh and or medic. Noeh also strives to promote the use of Sámi languages. However, the work of the association is based on volunteers and it is not possible to publish all communications both in Norwegian and in the three Sami languages spoken in Norway. Efforts have been made to translate texts on the website. On social media, each individual post is in the language/languages in which the individuals or organisations wish to communicate.

\section{Sáminuorra, Sweden}

Saminuorra is the oldest Sámi youth association in the Nordic region. It was established in 1964 , initially as a youth branch of the Swedish Sámi National Assembly (Svenska Samernas Riksförbund) but is now independent of business or party-political interests. It has more than 300 members. The association is funded through an annual gran from the Sámi Parliament, and by individual membership fees. Sáminourra's activities are centred on Jokkmokk, but it also has an active local branch in place in Östersund, with another one being es- tablished in the Stockholm/Uppsala region. It has a board comprised of 16 people, which makes all its decisions by consensus. The participants focus on meeting physically as often as possible, and they have four board meetings a year, usually lasting from Thursday to Sunday, and including a variety of activities. The meetings are held at different venues around the country.

Sáminuorra holds an annual weekend-long general meeting. The venue varies and the event attracts 70-100 Sámi young people each year. Other Sáminuorra activities range from pizza nights, to attending meetings at the Ministry of Enterprise and Innovation, to taking part in a lawEnterprise a d $\mathrm{EU}$ - namely, the People's Climate Case. ${ }^{8}$ Sáminuorra attends and one of its members also speaks at the annual Jokknok Market.

Sáminuorra is highly focused on approaches that will increase knowy focused on approaches that will increase knowledge of the Sámi in order ing a culture as stereotypically exotic), which are growing, in part due to a lack of information and understanding. The association is therefore especially concerned with the topic of education. For example, Sáminuorra had the chance to comment on a new school curriculum when it was launched in 2019. The new curriculum was meant to focus more clearly on knowledge requirements, and to facilitate the grading of students, In parallets to $f a-$ ciltate the rradng of studequs, In parallel, several changes were proposed for different subject areas. ity groups, including the Sámi, from years 7-9, and ity groups, including the Sami, from years 7-9, and instead to include it at an earlier stage, in years 4-6. The argument was that education about minority groups in the current system was spread out across different subjects, and that it would be beneficial for it to be centralised within civics education for year 4-6. However, the Sáminuorra board members met with the Swedish National Agency for Education and argued for keeping minority issues in years 7-9. They argued that the history of racism and oppression towards the Sámi people in Sweden is too difficult to understand for younger students, and that a deeper discussion was both needed and pos- sble for years 7-9. In the end the authority did indeed decide to keep minority issues as part of the curriculum for years 7-9. In terms of education more broadly, the association also works to promote better language education for Sámi children and young people, including opportunities for distance education and weekend courses

In order to address issues of discrimination against the Sami, and to create greater awareness of Sámi culture, Sáminuorra has introduced the Nuoras Nurrii (Youth to Youth) project, as part of which members of the organisation travel across the country to schools with students in years 7-9. For the association this has also been an eye-openerinterms of understanding how limited knowledge about the Sámi people is among Swedish young people. The schools welcome this initiative, because teachers recognise that they do not themselves have sufficient knowledge to teach Sámi topics. In other words, while the project is designed to promote awareness among young people, it also seeks to educate and create awareness among teachers. This particular project has been inspired by a similar initiative in Norway, which has been running for approx. 15 years. ${ }^{9}$ The Norwegian project started out as a three-year pilot scheme, after which the national parliament decided that it should become permanent It is now under the auspices of the Ministry of Local Government and Modernisation.

\subsection{Sámi Education Institutions and}

\section{Programmes}

This section provides an overview of Sámi educational institutions and programmes at the upper secondary, vocational and higher education levels Finland, Sweden and Norway.

The table provides an overview of the educational programmes which are offered across Sápmi today in vocational and higher education. This overview is divided into the themes which are the centre of our analysis in Chapter 3 - that is, languages, teachers, healthcare, reindeer husbandry, tourism, Sómi handicrafts, culture and the creative industries (e.g. journalism, music). 


\begin{tabular}{|c|c|c|c|c|c|c|c|}
\hline & Language & Teacher & Healthcare & Reindeer husbandry & Tourism & Sámi handicrafts & $\begin{array}{l}\text { Culture and creative } \\
\text { industries }\end{array}$ \\
\hline Vocational & $\begin{array}{l}\text { Inari Sámi Language } \\
\text { and Culture ( } 1 \text { year) at } \\
\text { the Sámi Education } \\
\text { Institute (FI) } \\
\text { Northern Sámi and } \\
\text { Language (1 year) at the } \\
\text { Sámi Education Insti- } \\
\text { tute (FI) } \\
\text { Skolt Sámi Language } \\
\text { and Culture (1 year) at } \\
\text { the Sámi Education } \\
\text { Institute (FI) } \\
\text { Sámi Language pro- } \\
\text { gramme ( } 2 \text { years) and } \\
\text { language courses at the } \\
\text { Sámi Education Centre } \\
\text { (SE) }\end{array}$ & & $\begin{array}{l}\text { Practical Nursing ( } 3 \text { years) } \\
\text { at the Sámi Education } \\
\text { Institute (FI) }\end{array}$ & $\begin{array}{l}\text { Reindeer Husbandry } \\
\text { (Specialised Upper } \\
\text { Level) } \\
\text { at the Sámi Education } \\
\text { Institute (FI) } \\
\text { Reindeer Husbandry En- } \\
\text { trepreneurship ( } 3 \text { years) } \\
\text { at the Sámi Education } \\
\text { Institute (FI) } \\
\text { Reindeer knowledge (2 } \\
\text { years) at the Sámi Edu- } \\
\text { cation Centre (SE) }\end{array}$ & $\begin{array}{l}\text { Nature Guide ( } 3 \text { years) } \\
\text { at the Sámi Education } \\
\text { Institute (FI) } \\
\text { Producer of Tourism } \\
\text { Services ( } 3 \text { years) at the } \\
\text { Sámi Education Insti- } \\
\text { tute (FI) } \\
\text { Receptionist ( } 3 \text { years) } \\
\text { at the Sámi Education } \\
\text { Institute (FI) } \\
\text { Travel Specialist (3 } \\
\text { years) at the Sámi Edu- } \\
\text { cation Institute (FI) }\end{array}$ & $\begin{array}{l}\text { Sámi Handicrafts or Arti- } \\
\text { san ( } 3 \text { years undergradu- } \\
\text { ate) at the Sámi Educa- } \\
\text { tion Institute (FI) } \\
\text { Sámi Handicraft Journey- } \\
\text { man (Upper Level) } \\
\text { at the Sámi Education } \\
\text { Institute (FI) } \\
\text { Master of Sámi Handi- } \\
\text { craft } \\
\text { at the Sámi Education } \\
\text { Institute (FI) } \\
\text { Handicrafts/ duodji (2 } \\
\text { years) at the Sámi Educa- } \\
\text { tion Centre (SE) }\end{array}$ & $\begin{array}{l}\text { Media (2 years) at the } \\
\text { Sámi Education Institute } \\
\text { (FI) } \\
\text { Sámi Culture (2 years) at } \\
\text { the Sámi Education Cen- } \\
\text { tre (SE) }\end{array}$ \\
\hline Higher Education & $\begin{array}{l}\text { Bachelor/Master's in } \\
\text { Inari or North Sámi } \\
\text { languages (from autumn } \\
2020 \text { also Skolt Sámi) } \\
\text { with subject teacher } \\
\text { at Oulu University (FI) } \\
\text { Bachelor/Master's/ } \\
\text { PhD in the North Sámi } \\
\text { language at University of } \\
\text { Helsinki (FI) } \\
\text { Bachelor/Master's/PhD in } \\
\text { North Sámi language and } \\
\text { literature at Sámi Universi- } \\
\text { ty of Applied Sciences (NO) } \\
\text { Bachelor/Master's/PhD, } \\
\text { 1-year and freestanding } \\
\text { courses in North Sámi at } \\
\text { UiT - The Arctic Univer- } \\
\text { sity of Norway (NO) } \\
\text { Bachelor Lule Sámi, free- } \\
\text { standing courses in Lule } \\
\text { and South Sámi at Nord } \\
\text { University (NO) } \\
\text { Freestanding courses in } \\
\text { South, North and Lule Sámi } \\
\text { at Umeå University (SE) } \\
\text { Freestanding courses in } \\
\text { North and South Sámi at } \\
\text { Uppsala University (SE) }\end{array}$ & $\begin{array}{l}\text { Teacher training, major } \\
\text { Subject } \\
\text { Sámi Language } \\
\text { at Oulu } \\
\text { University (FI) } \\
\text { Indigenous Pedagogy in } \\
\text { Teacher Training at Uni- } \\
\text { versity of Lapland (FI) } \\
\text { Kindergarten teacher, } \\
\text { general teacher training } \\
\text { for grades } 1-7 \text { and 5-10, } \\
\text { and a 1-year programme } \\
\text { in educational theory } \\
\text { and practice in North } \\
\text { Sámi at Sámi University } \\
\text { of Applied Sciences (NO) } \\
\text { Teacher training for } \\
\text { grades } 8-13 \text { in North } \\
\text { Sámi and courses in } \\
\text { North Sámi as part of } \\
\text { the teacher education at } \\
\text { other levels at UiT - The } \\
\text { Arctic University of Nor- } \\
\text { way (NO) } \\
\text { General teacher Educa- } \\
\text { tion for grades 1-7 in } \\
\text { South Sámi and in Lule } \\
\text { Sámi at Nord University } \\
\text { (NO) }\end{array}$ & $\begin{array}{l}\text { Nursing with Sámi spe- } \\
\text { cialisation, UiT - The Arctic } \\
\text { University of Norway in } \\
\text { cooperation with Sámi Uni- } \\
\text { versity of Applied Sciences } \\
\text { (NO) (under development, } \\
\text { starting in 2021) }\end{array}$ & $\begin{array}{l}\text { Bachelor/master's in } \\
\text { Reindeer Husbandry at } \\
\text { Sámi University of Ap- } \\
\text { plied Sciences (NO) }\end{array}$ & $\begin{array}{l}\text { Bachelor/master's in } \\
\text { Tourism and Travel at } \\
\text { UiT (not specific Sámi, } \\
\text { but northern and Arctic } \\
\text { focus) - The Arctic Uni- } \\
\text { versity of Norway (NO) }\end{array}$ & $\begin{array}{l}\text { Bachelor/ } \\
\text { Master's in Sámi handi- } \\
\text { crafts/ Duodji it Sámi } \\
\text { University of Applied Sci- } \\
\text { ences (NO) }\end{array}$ & $\begin{array}{l}\text { Bachelor/ } \\
\text { Master's in Sámi Culture } \\
\text { at University of Oulu (FI) } \\
\text { Bachelor/Master's in Jour- } \\
\text { nalism at Sámi University } \\
\text { of Applied Sciences (NO) } \\
\text { Freestanding courses in } \\
\text { joik/Sámi traditional music } \\
\text { at Nord University (NO) } \\
\text { Joint master's degree in } \\
\text { governance and entrepre- } \\
\text { neurship in Northern and } \\
\text { Indigenous areas between } \\
\text { UiT - the Arctic University } \\
\text { of Norway (NO) and Uni- } \\
\text { versity of Saskatchewan } \\
\text { (CA) } \\
\text { Master's in indigenous } \\
\text { studies at UiT - the Arctic } \\
\text { University of Norway (NO) } \\
\text { Freestanding courses in } \\
\text { Sámi culture and religion } \\
\text { at Umeå } \\
\text { University and Mid Swe- } \\
\text { den University (SE) }\end{array}$ \\
\hline
\end{tabular}




\subsubsection{Upper Secondary Education}

Sámi Upper Secondary School, Utsjoki, Finland

Utsjoki Upper Secondary School (Utsjoen Saamelais/ukio) was founded in 1977. The number of students ranges from 10 to 30 . It is possible to complete a high school curriculum in which all courses are taught in Finnish, but students can also take freestanding courses in Sámi. Depending on the mother tongue of the individual student, it is possible to take a Sámi language exam or a short foreign language syllabus. New courses have been added that are built around Sámi and Nordic themes along with Sámi language courses. In dic thencion with the Giellagas Institute at Ou University, they offer a Sámi culture course ond a University, they offer a Sómi culture course and a Sámi history course. Many courses are also rooted in the Sami tradition, e.g. music courses offered together with the Sami Music Academy in Utsjoki. The school also offers courses in Sámi food traditions and Sámi handicraft (duodji), which are taught in cooperation with the Sámi Education Institute (SAKK) in Inari. A double or a triple language degree is also available in cooperation with SAKK. The school also works with the University of Turku's Kevo Subarctic Research Station and the Natural Resources Centre in Utsjoki. The school is located at the same address as the Sámi Music Academy.

\section{The Sámi Upper Secondary Schools, Norway}

The Sámi High School and Reindeer Husbandry School (SVSRS) in Kautokeino and the Upper Secondary School of Karasjok are public-sector Sámi education institutions located in Northern Norway. SVSRS has approximately 130 students, of which a growing number are male, although the majority of them are female. The school's curriculum is embedded in the local needs and values of the Sámi language and culture. All students study Sámi language at different levels. The school is open to students from the whole country, but also from across Sápmi Like the Sámi Upper Secondary School in Utsjok, SVSRS offers both vocational and univer sity preparation programmes. New courses are being created to develop and strengthen the prevbeing created to develop and strengthen the prevalence of Sámi ethics and culture across the curriculum, including Sámi language, duodji, reindeer husbandry, restaurant/food processing, maths, and construction. In relation to the other upper secondary options, the school offers a wider range of Sámi specialisations, including vocational programmes such as construction science and equip- ment mechanics. It also offers distance learning courses in Sámi for students at other upper secondary schools.

\section{Upper Secondary School of Lappland, Sweden}

In Sweden, Upper-secondary School of Lappland, on the same premises as Bokenskolan, is the only such institution in Sweden offering education in Sámi. Located in Jokkmokk, in Northern Sweden, the school has around 175 students and offers one Sámi programme - for which all the approximately 15 students are, currently, female. The programme has a specific focus on Sámi society. Sámi languages (North, Lule or Southern), as well as Sámi history and languages. Apart from the as Sami also attend courses in Sámi culture, guide training reindeer knouledge and a specific subject in entrepreneurship, as well as Sámi handicraft/duodji. The handicraft courses are specifically intended for the Sámi programmes, which includes tree and horn or skin and textile work. Parts of this educational programme takes place at the Sámi Education Centre, also located in Jokkmokk.

\subsubsection{Vocational Education}

\section{The Sámi Education Institute, Finland}

The Sámi Education Institute (SAKK) is a vocational upper secondary education institution founded in 1993. It has branches in various places in the municipality of Inari, in Northern Finland. SAKK has around 750 students at three different campuses, and organises multi-disciplinary professional education in both Finnish and Sámi languages, as well as promoting Sámi culture. The institution arranges physical and distance learning classes, workshops and degree programmes for young adults and mature students. The core curriculum supports the livelihoods of the Sámi people with an emphasis on the development of the Sámi languages and cultures, in order to promote nature-based occupations and employment. The Institute works in collaboration with other institutions nationally and internationally, to preserve and develop indigenous coltures, and the liveli-

Business and administratio

Data-processing

orth or Skolt Sám

Media

Nature guide, tourism services producer,

receptionist, travel specialist
Practical nursing

Reindeer husbandry entrepreneurship

Sámi handicrafts or artisan training

- Chef

Waiter.

As part of the Institute's entrepreneurial efforts, one of the main goals for the reindeer husbandry programme is to develop business skills. This is done in order to equip students for other outdoor professions and develop their business plans so that they are able to support their families as self-employed business owners.

\section{The Sámi Education Centre, Sweden}

Samernas Utbildningscentrum, or the Sámi Education Centre (SEC), is a school for upper secondary education and vocational training in Jokkmokk Northern Sweden. The centre was founded in 1943 as the Sámi Folk High School, but it changed status in 1999 when it adopted its current form. The Centre has around 150 students and offers additional short courses. It runs several courses on aspects of reindeer husbandry, as well as workshops and evening courses, which operate by inviting in different businesses, as well as a longer, two-year course in Sámi handicrafts (duodji). But the courses offered are mainly of the shorter variety:

- Two-year training in duodji

- Cross-border education for reindeer herders, including students from Finland and Norway

- North Sámi, Lule Sámi, Ume Sámi and

Southern Sámi languages

- Sámi history, culture and reindeer knowledge.

The Sámi Education Centre in Jokkmokk is especially well known for its duodji programme, attracting students from across Sápmi.

\subsubsection{Higher Education}

The Giellagas Institute, Oulu University, Finland Founded in 2001 at the University of Oulu, the Giellagas Institute has a nationwide responsibility to organise, introduce and provide Sámi language and cultural studies and research in Finland. As a part of the Faculty fers two major academic subjects, namely Sami fers two major academic subjects, namely Sámi Language and Sámi Culture. In Sámi Languages (North, Inari and Skolt Sámi), the major teaching language is Sámi, while the studies in Sámi Culture require skills in Finnish, in addition to Sámi and English. Graduates in Sámi Language at Oulu are employed as teachers, for example. This requires courses in Sámi culture and literature, as well as pedagogy. The Giellagas Institute also offers a minor subject option in North Sámi as a foreign language. The aim of the Institute is to equip researchers, teachers and other professionals with deep knowledge of Sámi cultures and languages.

\section{University of Lapland, Finland}

Located in the city of Rovaniemi, the University of Lapland (ULapland) is a higher education institution in the northernmost part of Finland. It focuses on the people, communities and environ focusthe Arctic, international tourisn research and susthe Arctic, international tourism research and susSámi for navive speks. This can besu in North Sámi for native speakers. This can be supplemented with specific teacher training course in Indigenous Pedagogy (IPED). For non-native speakers, students can complete language courses in Sámi at the University's own Language Centre.

University of Helsinki, Finland

The University of Helsinki offers Sámi Studies as a distinct discipline. This includes both research and degree programmes. Sámi studies focuses on the Sámi people, their languages, culture and history. The languages are studied within the framework of minority issues and ethnohistory. Sámi Studies also focuses on questions of Arctic nature, northern ecology, and changes to the nature of Sámi livelihoods. The linguistic focus for Sámi studies at the University is North Sámi.

\section{Sámi University of Applied Sciences, Norway}

\section{(SUAS)}

Sámi Allaskuvla, or Sámi University of Applied Sciences (SUAS), is an indigenous Sámi institution of higher education and research, established in 1989 placed in Kautokeino, Northern Norway. The University college has around 175 students, of which approximately $80 \%$ are female. More than $20 \%$ of students are international, including those from Sweden, Finland and Russia. 10 The school was originally established to offer Sámi teacher training in the Sámi language and in a Sámi-language environment. Since 2005, research on Sámi cul- 
ture has been further strengthened through collaboration with the Nordic Sámi Institute, funded by the Nordic Council of Ministers. All teaching is grounded in a Sámi perspective.

Developing Sámi as an academic language is one of the institutions' priorities and responsibilities. SUAS is the only higher education institution in the world that uses one of the Sámi languages (North Sámi) in almost all its activities (except for the Masters programme in indigenous journalism, which is international and conducted in English). SUAS runs approximately 40 courses, including stand-alone ones, e.g in languages. Masters and Bachelor level programmes are offered in:

Sámi teaching at both primary and secondary school levels

- Sámi Language and Literature (in which it is possible to continue with a PhD)

Indigenous Journalism

Sámi Traditional and Applied Arts (duodji)

- Reindeer Husbandry.

\section{UiT - the Arctic University of Norway}

UiT - The Arctic University of Norway is a driving force in the implementation of the Norwegian Government's strategy for the High North. This means that the University is committed to offering northern and Arctic studies. Among the key focus areas, the University runs North Sámi language programmes at Bachelor and Masters level for native speakers. It also runs one-year programmes in North Sámi as a foreign language, as well as a native language. All programmes are primarily taught in Norwegian, but exams are in Nor Sámi. UiT provides teacher training for grades 8-13 in North Sámi, as well as courses in North Sámi as part of teacher training at other levels.

Along with SUAS, the University is currently developing a nursing programme with a Sám specialisation in order to address the shortage of nurses who speak Sámi and understand the culture. A national curriculum for a nursing programme with a Sámi specialisation will be deveoped in 2020-2021.

Although they do not have a specific Sámi focus, the Bachelor and Masters programmes in Tourism and Travel at UiT are relevant because they focus on the northern and Arctic regions. Finally, UiT offers a Joint Master's degree in governance and entrepreneurship in Northern and Indigenous areas, in cooperation with University of Saskatchewan (CA), as well as a Masters programme in indigenous studies. Both of these attract many international students.

\section{Nord University, Norway}

The Nord University is spread across different locations in Central and Northern Norway. It runs a bachelor programme in Lule Sámi, freestanding courses in Lule and South Sámi, and general teacher training for grades 1-7 in South Sámi and in Lule Sámi. Students also have the option of attending a 30 ECTS course as well as shorter courses in joik, which can be taken as part of teacher training or other education programmes.

\section{Umeå University, Sweden}

Umeå University has housed a Centre for Sámi Research, Várdduo, since 2000. The unit focuses on presenting sharing and initiating new Sámi and Indigenous research. Ume University offers multiple freestanding courses in the Sámi languages (Southern, North and Lule), from lower to advanced levels, and also Sámi cultural studies.

\section{Uppsala University, Sweden}

Uppsala University runs several courses in Sámi that is, both Sami culture and language courses. The language courses are offered at basic and advanced levels in North Sámi and South Sámi. The language of instruction is in Swedish. The University also runs a course in Sámi Culture and Society.

\section{Analysis: Youth Perspectives, Education and Labour Market}

\subsection{Sámi languages}

\subsubsection{Youth perspectives}

For this study, we interviewed Sámi young people who grew up in areas where Sámi is the first language for the tionalinstivulions are based. We also interviewed Sámi young peoplewhogrew up elsewherein three countries. Some of those for whom Samiwas not a first lons of thos whom Sami was not aurge languge as children had taken some language lessons. But generally the quality of this was limited, and it has not left them with strong language skills. This is the case with regards to teaching in North Sámi, South Sámi, Lule Sámi, and the smaller Sámi language groups. Some of the young people have only had the opportunity to take distance learning courses, which has been challenging. The Sámi young people interviewed for this study who have not had Sámi as their first language acau language ac ing Sami upper secondary school and/or university "Growing programme.

Growing up / tried to take Sámi language lessons, but there was a lack of teachers. It was not aways possible, and the teaching was not very good. When I moved to Kautokeino everyone spoke Sám and I had a good teacher at school. I soaked up all of the cultural knowledge I possibly could." (Young female, NO)

Language is a significant pillar of culture. Therefore, as described by interviewees, acquiring the language also involves gaining a stronger understanding of the history and culture of the Sámi peop This is so not least at Sámi education institutions. where language education is closely connected to where language education is closely connected to, for example, learning about the traditions of reir deer husbandry, handicrafts and Sámi music.

"We didn't really learn anything about our own culture in school. I started leaming about it at university. Now that I have the language, there is so much I can do, for example translations, interpretation, write education material. (...) I have a friend who teaches Sámi language remotely while living abroad. Modern technology makes this possible." (Young female, $\mathrm{Fl}$ )
In general, there is a strong awareness among the young people concerned that Sámi language skills provide a viable basis for them to construct a working life rooted in Sámi culture.

3.1.2 Challenges and opportunities: education and labour market

Maintaining Sámi languages is a priority for the Sámi parliaments and, as described in the previous chapter, it is an area in which they have forged effective cooperation. For the Sámi parliaments in Norway and Finland, which have responsibilities in the area of education, this work is strongly linked both to education and to meeting needs in the labour market. For example, Sámi parliaments are concerned with the requirement for Sámi language teachers. One concern is how the many Sámi children and young people living outside the Sámi-speaking centres can also receive language education.

"If you have studied the language, there is also an urge on some level to work for the Sámi community and preserve the culture. It is important considering how few Sámi speakers there are, and how desperately services in Sámi language are needed." (representative, Sámi Parliament)

Interviewees from Sámi educational institutions agree that the need for Sámi language skills in the labour market is extensive. That is, regardless of which education programme a Sámi young person attends, language skills form the basis for the subsequent work opportunities.

3.1.3 Sámi teacher training: a political focus A key political priority for the Sámi parliaments in Finland and Norway is the need for Sámi teachers. This is also strongly connected to maintaing the Sámi languages. The necessity of recruiting more Sámi teachers is also a concern in Sweden. However, the Sámi Parliament there does not have a mandate to work in the education policy area.

"Most important is the Sámi language. Sámi identity. The young people need to feel safe and self-confident. They should not feel that they need to hide that they are Sámi (...) It is problematic that 
we have a large group of Sámi people who do not speak Sámi. It is a vicious circle when you cannot find Sámi teachers." (Representative of an educational institution)

Sámi University of Applied Sciences (SUAS) was established initially with the specific purpose of providing Sámi teacher training. Today, training Sámi teachers is still an important function of the University.

"This year approximately 10 new Sámi teachers are needed in order to cover the needs in Sám schools in Norway. In practice this is what you need to keep the language alive." (Representative of an to keep the language altional institution)

The teacher training at SUAS is subject to Norwegian legislation, but the teaching is in North Sámi, and pedagogical training is rooted in Sám cultural values. This means, for instance, that Sámi musical traditions are incorporated into the teaching. SUAS, funded by the Swedish Education Authority, also regularly hosts competence development courses for Sámi teachers, in Jokkmokk. In Norway and Finland, universities run teacher training programmes for teachers in the various Sámi languages.

\subsection{Healthcare}

\subsubsection{Youth perspectives}

The need for Sámi-speaking personnel with knowledge of Sámi culture in healthcare services is concern for cross-border cooperation, including among the Sámi parliaments' youth councils. Today, there is only one facility in Norway (SANKS in Karasjok) which offers psychiatric treatment in a Sámi language. Patients are also referred from Finland and Sweden. The youth councils have been discussing opportunities for cross-border cooperation - e.g. the potential for public bodies to share Sámi healthcare personnel. One of the Sámi young people interviewed for this study is a psychiatric nurse, living in Finland. He highlights opportunities for cross-border education, which is today limited by the requirement to speak the national language.

"I would like to specialise and train in psychotherapy. I understand that the university hospital in Tromsø offers multiple specialisations. But I would have to know Norwegian. It can't be done throug the medium of Sámi." (Young female, FI).
3.2.1 Challenges and opportunities: education and labour market

The needs for Sámi competences in the healthcare system has become a growing concern for the Sámi parliaments. In Finland, a practical nursing programme is run at SAKK. In January 2020, a Sámi nursing programme started at SUAS in Norway in collaboration with the Arctic University of Norway (in Tromsø), which provides the nursing training, while SUAS provides the training in Sámi language and cultural competence.

"Sámi patients have their own approach to disease and pain Communication challenges have esease ally been observed between children and lderly patients and healthcare personnel."

The Sámi nursing programme has largely come about because of the need identified by the Sám Parliament in Norway. Similarly, the Finnmark County Police and the Sámi Parliament are in dialogue with SUAS about developing a similar Sám specialisation for a police education programme. The police have themselves observed the need for Sámi language and culture skills.

\subsection{Reindeer husbandry}

\subsubsection{Youth perspectives}

Today, only a small proportion of Sámi people have reindeer husbandry as their main occupation. The youth associations and the Sámi parliaments' youth councils are very much concerned with reindeer husbandry, however, and they are now addressing the challenges linked to maintaining its sustainability within Sápmi.

Sámi young people across Sápmi highlight the same challenges for the future of reindeer husbandry. Land use conflict is a key concern - that is, competing interests, which today are still a major factor in disputes between the Sámi and the Nordic nation states on largescale projects such as railroad infrastructure, hydropower, wind turbines and mining. Moreover, the effects of climate as ralroad infrastructure, hydropower, wind turthange are visible in Sapmi, and already affecting the grazing conditions of reindeer, for example. Predators (e.g. Wolves) pose another significant challenge for reindeer husbandry. Regulation is in place in each of the countries as to how many reindeer each cooperative/district may own. Future possibilities therefore depend upon the number of reindeer you can own, or your family owns. As a result of these challenges a future as a full-time reindeer herder is not always possible, or it may only be realistic as a part-time occupation or leisure activity.

"Young people in some Sámi cooperatives (samebyer) realise that in future not all of them will be able to support themselves as reindeer herders. They need to consider who will leave the cooperative for others to be able to continue. It is painful to have to make this decision when it is what you have grown up with and a strong part of your culture and identity." (Young female, SE).

We have interviewed Sámi young people who have attended educational programmes at upper secondary or vocational education institutions. In reindeer husbandry a lot of the knowledge needed is acquired from family members and from the practical work experience, something which these young people have gained growing up with reindeer herding. One of the things students learn at school is the economic aspect reindeer herding, for example, how to manage sales to slaughterhouses, and how to maintain a balance with the costs of having a snowmobile or other equipment needed. Through our interviews we learned that some of the young people would have liked a stronger focus on the specific rules and regulations that influence reindeer husbandry, as well as on entrepreneurship. Many young Sómi will need to compreneurship. Many young Sámi will need to combine reinder hus you ry with another occupation. In order to provide the flexiblity needed, this may also involve competences in self-employment and entrepreneurship.

"I wonder if I should study something else, so that I can also work with computers, something ITrelated. Reindeer herding is not a five days per week job (...) It can be challenging to find a job that has that kind of flexibility, where you can leave from one day to the next to tend to your reindeer." (Young male, SE).

Food processing and food production related to reindeer are highlighted by some Sámi young people as future oppotunities. According to tradition, the Sómi utilse all of the reindee for vaious purposes, whereas at slaughterhouses today some of the carcass is thrown out.

3.3.2 Challenges and opportunities: education and labour market

The upper secondary school at Kautokeino runs a reindeer husbandry programme, which combines two years in school and a two-year apprenticeship programme. The school also offers a Sámi chef/ cooking programme. The upper secondary school in Sweden has previously tried to develop a programme focused on reindeer herding, but it found that this was not what the students wanted. Today, knowledge about reindeer herding is more closely integrated into the various programmes at the upper secondary school.

"The students actually know most of what they need to about reindeer herding, if that is what they want to do. What they need is more supporting competences such as a truck drivers' licence, welder training, construction training, and so on. This is to make them able to combine reindeer herding with for example, starting their own construction womfor exa" (Represtarting their awn construction company."
tion)

The upper secondary school in Kautokeino and the Sámi vocational education institutions on the Swedish and Finnish sides have also worked together on a joint project, co-financed by Interreg Kolarctic, which brought together students from different locations to learn about reindeer herding across borders.

Higher education in reindeer husbandry is only possible today at SUAS in Kautokeino. The Bachelor and Masters programmes were set up to meet an identified need both within the industry and in the agencies responsible for reindeer husbandry. However, the University still finds it hard to recruit students, partly because the programme Is new and needs to be better known. One way to improve links with the labour market would be to include internships as part of the programme, another would be to boost the University's profile entrepreneurial profile.

\subsection{Tourism}

\subsubsection{Youth perspectives}

Many tourists visiting Sápmi are interested in indigenous cultures. This entails both challenges and opportunities for the Sámi people, especially the reindeer herders. The opportunities lie in the potential for the Sámi people themselves to develop authentic tourism experiences, e.g. in combination with reindeer herding. Challenges arise when others develop activities for tourists give a wrong impression and representation of Sámi culture. Examples of this has been observed in Finland, where international tourism was the first to grow - espe- 
cially around the Santa Claus Village in Rovanie$\mathrm{mi}$ and at popular ski resorts. Other challenges involve nature-based tourism, e.g. snowmobiles and dog sledges, which can clash with the needs of reindeer herding. This problem seems most pronounced in Finland. Developing tourist attractions can also conflict with the annual cycle of reindeer herding, because tourists arrive at times of the year where reindeer herding requires concentrated effort and time.

None of the Sámi youth interviewed for this study see tourism as a central opportunity for their future working life. They highlight concerns about the development of mass tourism, which about the developme. they also perceive po sential in the developmever, they also percive potential in the development of a responsible/ethical type of Sami tounism. They also recognise links to duction and reindeer.

"We need more branding to place focus on Sámi food production and reindeer as ethical meat. We can tell the whole story of the journey the meat makes from nature to the consumer's plate. Reindeer are important for Sámi handicrafts as well. The whole reindeer is used." (Young female, FI)

Some young people highlight the need for education and the appropriate competences needed to build sustainable tourism businesses.

"It would be cool to build up something from here and give back to the local community. To do that you need the right competences, for example in marketing." (Young male, SE)

In general, the Sami young people interviewed highlighted cultural sustainability in the development of Sámi tourism as something they considered important.

3.4.2 Challenges and opportunities: education and labour market

Today, education programmes in Sámi tourism in Finland are offered only at the Sámi Education Institute (SAKK). There are four different programmes related to tourism: for nature gudes, tourism services, travel tionists. In these programmes, the developentof etsical and culturally sustainate toursm is a of ethical and culturally sustainable tourism is a core concern. Students who attend the reindeer husbandry programme at SAKK also learn about tourism.

At the upper secondary school in Jokkmok a nature guide course is offered to students. This allows those who discover an interest in it to look for other educational opportunities in the field of tourism later on. In Norway, Sámi education institutions do not offer programmes centred on Sám tourism. However, they refer to plans for the future which will place more focus on entrepreneurship and on the different opportunities for starting up a business, which may include specific opportunities in tourism.

The upper secondary school in Kautokeino and SAKK also offer programmes in restaurant/food processing and chef/waiter training, which may lead to jobs linked to Sámi tourism.

\subsection{Sámi handicrafts (duodji)}

\subsubsection{Youth perspectives}

Sámi handicrafts (duodji) which include, e.g. the production of Sámi knives and Sámi jewellery, are rooted in nature and reindeer herding. The handcrafts involved differ between different areas. For instance, the design of Sámi dress can differ. Sámi handicrafts are traditionally made at home, and the skills are learnt within the family. Traditiona knowledge and practical skills in Sámi handicraft creation have not been maintained in every household, however. This makes institutional educational opportunities important. We have interviewed Sámi young people who have learned some handicrafts from parents or grandparents, and some from tran parents or grandparents, and some from taking courses at upper secondary school or at vocationaleducation centres. For talented indviduals there are job opportunities across Sáp

Ong the production of Sami handicrafts.

One of the young people interviewed for this study is currently doing a two-year apprenticeship in duodji, following two years of education at the upper secondary school in Kautokeino. She is also a board member for the Sámiid Duodji, an association which works to improve framework conditions for Sámi handicrafts in Norway.

"Most only work with Sámi handicrafts as a leisure activity. We are the only indigenous people in the world who can get a degree in culture-carrying crafts, duodij and reinder herding But few choose to tak the centificat Tsue is that job op of aprites hove not baybe the issue is that job opportunities have not been sufficiently promoted. We are trying at Samiid Duodji to ddress this." (Young female, NO)

The association is also working to prevent the mass production of copies of indigenous handicrafts, which are then misleadingly marketed and sold as authentic Sámi products. This is based on a development that have been observed in Finland, where tourists are buying the copied products rather than the real ones made by Sámi people themselves. The pricing of genuine Sámi handicrafts is significantly higher, because of the many hours that are spent on each individual product. The main purpose, however, remains to sell the products within the Sámi community. There is a strong sense of community among key education institutions, organisations and associations working with Sámi handicrafts across Sápmi. Meeting places include Jokkmokk Market, Arctic Skills, and the Riddu Riđđu festiva.

3.5.2 Challenges and opportunities: education and labour market

Sámi handicrafts training is available at Sám upper secondary schools. In Kautokeino it is possible to choose it as a specialisation, and then to continue with an apprenticeship. In Jokkmokk an Inari, Sámi learning about handicrafts is part of Somi fearning about handicrafts is part of interested in programme. For those who become this at the Sámi vocational education centres. It is also possible to choose higher education in duodji at SUAS.

Similarly, as regards reindeer herding, duodji is a new field for the higher education level at SUAS. There is also still a struggle to recrut students at this level. The background for establishing Bachelor and Masters programmes is that there is a need for teachers who have an academic degree in handicrafts, for designers at theatres, and for more research in the field generally. Students con also go on to do a PhD in the field of duodji.

\subsection{Cultural/creative industries}

3.6.1 Youth perspectives

The Sámi young people talk about cultural industries as future development opportunities, but also as being important in their own right in order to nurture their sense of identity. Art especialy music, music, along with festivals, media and film production, are areas which are highl tant by Sámi young people.

In recent years, young Sámi musicians have made breakthroughs in both Finland, Norway and Sweden. They have become idols not only for Sámi young people, but also for non-Sámi. These musicians sing in Sámi and help to communicate Sámi culture to the majority population. This helps break down some of the of the prejudices that still exist. These developments also promote the use of Sámi language among Sámi young people.

"Amoc is an artist making rap music in the Inari Sámi language. He is a role model for children and young people, and he helps to keep the Inari Sámi language alive." (Young female, FI).

One of the young people engaged in reindeer herding who was interviewed for this study also sings (jojk). He is part of a music group in the local area, and he provides entertainment at both private and public events. Jojk is closely connected to the traditions of reindeer herding and the young reindeer herder we talked to sees potential in making part of his living from singing, including "Jojk is a hobby, but it is

(Yis also a big part of who I am. I grew up with it." (Young male, NO).

The Sámi festivals are also brought up in interviews as significant meeting places, and as opportunities to enjoy Sámi culture. As described above, these are also important venues for the sale of Sámi handicrafts.

When I think about the issue that women, especially, leave the rural parts of Sápmi - this is also because there is a lack of art and culture on offer (...) This is why the Sámi festivals are so important They are held in small locations, focus on Sámi culture, and become a meeting place to speak the Sámi language." (Young female, NO)

Young people in Norway, particularly, noted development in the field of Sámi film production as significant. This is to a large extent coming from the Kautokeino area, where the International Sámi Film Institute is based. It also stems from the journalism programmes at SUAS, which has become increasingly focussed on film production.

3.6.2 Challenges and opportunities: education and labour market

The upper secondary schools include Sámi music as part of their programmes. At Nord University in Norway it is also possible to take a 30 ECTS course, as well as shorter courses in joik, which can be taken as part of teacher training or other programmes. SAKK in Finland offers vocational training in media. At SUAS in Norway it is possible to study journalism at both Bachelors and Masters levels. The Bachelor programme is in Nort Sami and the Masters programme is in English. The degrees are in line with national curricula for journalism, but with a Sámi focus. For the Mas- 
ters programme, there is an indigenous and Arctic focus. The University also runs standalone skills enhancement courses, which are often attended by journalists (or people working with journalism (who do not have a journalism degree)). Because of a lack of Sámi speaking journalists, a number of employees in the industry do not have a degree in journalism. This also means that there is a high demand for the students who graduate from these particular journalism programmes.

In accordance with the general trend and demand in the media industry for people with crossmedia skills, the BA programme has evolved to include a specialisation in film production. For this specific purpose, collaboration has been tablished between the University and the established betwioni Film Instivte, also based Kautokeno. As part of their education, students Kautokeino. As part of their education, students acquire the skills to produce documentaries and ther film genres.

"We have worked to establish a strong profile in film production. The perspective needs to change. Many have come here to produce films about us. Now we need to tell our own story. (...) Five of our students will screen their films at the coming Indigenous Film Festival in Inari [skábmagovat]. I am very proud that they made it through at a festival with over 1,000 visitors." (Representative of an educational institution)

The International Sámi Film Institute has established an international reputation. It is part of an international network of indigenous film producers. The Institute has also established coop- eration with the national public service company, NRK, in the production of a drama series with (and about) the Sámi. Sámi radio stations which are part of the national broadcasting organisations, NRK, SVT and YLE, also have an established collaboration. This means that there is a good coverage of Sámi-related news across Sápmi. This was further strengthened through an EU Interreg project, which established links with Sámi stakeholders in Russia, enabling them to set up their own Sámi radio station. As part of this project, SUAS was involved in providing competence-based development for the future staff of the Sámi radio station in Russia, with a particular focus on ethics and on producing with a particular focus on ethic

"I hope that in future the Sámi media will become more involved in developing journalism programmes for Sámi students who are eager to learn how to communicate news which is important for us and others, with a strong ethical point of departure." (Representative of an educational institution)

Disney has recently been in dialogue with the Sámi parliaments about the preparations for Frost 2, which has used Sámi cultural elements. It was a good dialogue by all accounts, and it was also decided that a translated Sámi version of the movie would be launched. However, this development has also led to some nervousness among Sámi stakelolds. They are concerned about what the movie might generate in terms of interwhat the movie might generate in terms of interscapes and cutsure exhibited in the move the land-

\section{Conclusions}

The purpose of this research has been to create an overview of, and to enhance knowledge about, the current status of links between the perspectives of Sámi young people on regional development and education institutions - as well as identifying challenges and opportunities for strengthening those connections. In the following, we synthesise the findings of our study, highlighting its main conclusions and identifying further implications for regional development.

4.1 Sámi language skills provide a strong basis for strengthening selfconfidence, cultural identity and job opportunities

Measures are being taken in Finland, Norway and Sweden to support Sámi language education for children and young people living outside the Sám speaking centres of the countries. There is a history of oppression of the Sámi people by the majority society in these countries, which has contributed to Sámi living outside the Sámi-speaking centres losing their indigenous language. A key challenge today is that there are not enough qualified Sámi tanguage teachers, which has a negatived Sámi on maintaing Sámi languages. It is possible to study the different Sani languages and to study to be a Sámi teacher at various educational instito be a Sami teacher at various educational institutions in Sápmi. However, maintaining the Sámi languages is a concern for both Sámi parliaments and for Sámi educational institutions. An example of how this issue can be addressed is to be found in Norway, where the Sámi Parliament offers grants to students who choose to study to become Sámi teachers and to study Sámi languages.

Language is a strong pillar of culture, and it has also been highlighted as such in this study, especially by young people who have not grown up with Sámi as their first language. Sámi educational institutions play a key role in providing this education, but also in providing Sámi youth with much-improved knowledge of their cultural heritage. Interviewees have highlighted that education, with the Sámi language as its basis, has a significant role to play in creating a sense of pride in the Sámi culture and providing young people with a stronger feeling of self-confidence. This in turn provides Sámi young people with a foundation to create a positive working life, which can either be directly linked to traditional Sámi occupations, or not. As has been identified, one of the priorities for Sami youth organisations is working to build selfconfidence and pride among Sámi young people - for example through working on anti-discrimination measures directed at non-indigenous youth.

Significantly, in addition to the traditional occupations of reindeer husbandry and Sámi handicrafts, there is high demand in the labour market for candidates with strong Sámi langua market ture skills - e g in the areas of education, public thation, healthcare, the police force, the media industry and other creative industries.

\subsection{Sámi-related jobs and new region-} al development opportunities

Through our interviews with Sámi young people, some who wish to have a future in reindeer herding also realise that they need to combine this traditional occupation with another job. An important aspect of the 'second job' is that it needs to be flexible, in order to allow time for reindeer herding which cannot always be neatly planned and timed. Sámi educational institutions address the need to combine occupations to some extent, recognising that is often a necesity for people working with Sámi handicrafts as well. A viable approach by these education institutions to preparing young people for a future work life with more than one occupation would involve providing them with the skills needed to run their own business, alongside entrepreneurship training. Some Sámi young people interviewed for this study have indicated that additional entrepreneurship training would have been useful as part of their education.

Tourism is one of the sectors - as also highlighted by the OECD (2019) - in which there is potential for Sámi entrepreneurship. In general, Sámi young people who took part in this study see the potential that the development of ethical and socially and environmentally sustainable tourism creates. However, they also observe tendencies that concern them, such as mass production of copies of Sámi handicrafts, and mass tourism, mainly in areas of Finland. The SAKK vocational school in Finland has educational programmes in place which focus on Sámi tourism, and it is also 
possible to attend the programmes in Tourism and Travel at UiT (the Arctic University of Norway), which focus on the northern and Arctic regions. Sámi music and food production/chef training are other areas highlighted as possible part- or fulltime occupations linked to the Sámi community, but also with potential links to tourism.

The media is an area in which there is a clear demand for Sámi language skills and cultural competences. In response to this demand, the higher education institution, SUAS, runs programmes in journalism. These programmes have a strong focus on providing students with an ethical approach to indigenous journalism. SUAS also foproach to indigeng journ wism an mentary film production, which involves a close mentary film production, which involves a close cooperation with the International Sámi Film Institute and with the Sami divisions of the national public service corporations (NRK, SVT, Yle). Sámi young people also identify potential in the fields of arts (e.g. music, theatre, literature and text production, and handicrafts). There are a variety of ways in which the roots of Sámi culture and language can shape the future working life of Sámi young people, without directly depending upon an individual maintaining links to traditional Sámi occupations, for example by being part of a reindeer herding family.

\subsection{Challenges and opportunities for} cross-border cooperation

Historically, and to this day, the Sámi people and Sámi languages straddle the national and administrative borders of Finland, Norway, Sweden and Russia. From this perspective Sámi educational institutions are also attractive for Sámi young people across the four countries. As illustrated in Chapter 2 of this report, the kind of education offered at Sámi educational institutions spans different Sámi specialisations, and is linked to job opportunities in many different fields.

Regarding education, however, there are crossborder obstacles concerning profession-oriented programmes, such as for teachers and nurses. These are education/training programmes which require, in part, a national-specific curriculum. Moreover, in a cross-border situation, languages used at educational institutions will often vary between Sámi and the national language, which can be a challenge for the individual student ( though this is less of an issue between Sweden and Norway). SUAS, the only indigenous higher education institution in
Sápmi, has Sámi students and strives to attract more Sámi students from neighbouring countries. SUAS works with the Sámi parliaments and other educational institutions in Sápmi - currently with the Sámi Parliament in Finland, for example, to ensure that the teacher training programme at SUAS can be adapted to authorise graduates to work in Finland without additional training.

The EU Interreg programmes have played a role in facilitating cross-border collaboration between Sámi educational institutions and other Sámi stakeholders. The Sámi Parliament in Sweden does not have authority in the field of education, which means that in principle cross-border political cooperation in this area is not possible. However, the Sámi parliaments have joined forces to work towards language standardisation. This work was initiated through an EU Interreg project, work was initiated through an EU Interreg project,
in which educational institutions across Sápmi were involved in developing the Nordic Resource Centre for Sámi Languages. In 2020, this work towards language standardisation continues, with a focus on the largest language group, North Sámi, coordinated by the Sámi Parliament in Norway. Another EU Interreg project has strengthened cooperation between reindeer husbandry training programmes across Norway, Finland and Sweden, bringing together students to learn about differbringing together students to learn about differjournalin a EU Interreg profect has foclited journalsm, an EU Interreg project has facilitated in Russia, and has helped to exp a journalists in Russia, and has helped to expand the broadcasting of Sami radio to Russia. This builds on an established framework of cooperation between the national public service organisations - NRK, SVT and Yle. These are projects that help build networks across borders.

Notably, EU Interreg funding opportunities may involve untapped potential for Sámi youthcentred projects, including projects developed by young people themselves. At present, the youth associations do not have well-developed crossborder cooperation, although they see possibilities for strengthening such links - including those with Sami young people in Russia. Theyoung those with Samiyoung people in Russia. The youth associations have similar activities today, for example, they are actively involved in annual Sami events that attract participants from across Sápmi. There may also be potentials for establishing cooperation via organised meetings held at Sámi events, which may attract young people and representatives of their associations across borders.

\section{Method and list of interviewees}

A key methodological consideration for this study has been that none of the researchers involved are themselves indigenous Sámi. We have therefore integrated ethical and reflexive considerations into the design of the methodology, which ensures that Sámi stakeholders interviewed for the study have had the opportunity to comment and provide quality assurance on the draft of the final report.

The data collection has comprised a combination of desk research and qualitative interviews. Interviews have been conducted with three stakeholder groups: Sámi parliamentary representatives, Sámi young people, and Sámi educational institutions.

Sámi Parliament representatives: A total of three representatives from the Sámi parliaments with responsibilities in the areas of business development and/or education were interviewed for this study. In Finland, two interviews were also conducted with young people working at the Sámi Parliament (listed under Sámi young people). They therefore responded to questions concerning the both the Sámi Parliament and youth perspectives. The purpose of conducting interviews with representatives of the Sámi parliaments was to gain insight into the political framework conditions pertaining to the Sámi parliaments, their capacity to influence Sámi education policy and the links between education and regional labour markets and regional development.

Ulla Aikio-Puoskari, Education Secretary, the Sámi Parliament in Finland.

- Rune Sverre Fjellheim, Director, the Sámi Parliament in Norway.

- Ingela Nilsson, Head of Business Development, the Sámi Parliament in Sweden.

Sámi young people: $A$ total of 12 Sámi young people, aged 18-29, were interviewed for this study (four from each country). Politically independent Sámi youth associations exist in each of these countries. Initially, the purpose was to conduct countries. Initially, the purpose was to conduct
interviews with representatives from all associations, in order to gain a better understanding of tions, in order to gain a better understanding of
civil engagement and the perspectives of Sámi civil engagement and the perspectives of Sámi
young people. However, it was not possible to esyoung people. However, it was not possible to establish contact with the association in Finland. The interview data thus varies somewhat between the countries. In Norway and Sweden representa- tives from the associations have been interviewed, Parliament Youth Council was interviewed instead. Furthermore, we have strived to achieve a balance between the participation of young people who have grown up in Sámi speaking centres (North Sámi, because this is where the Sámi education institutions are based) and young people who have grown up elsewhere in the three countries.

The overview below of the Sámi young people interviewed for this study indicates gender, age group (18-24 or 25-29 years old), place of residence (including where they were brought up), and education/occupation:

Male, 18-24 years old, Inari area, education reindeer husbandry at The Sámi Education Institute (SAKK)

Female, 25-29 years old, Inari, education: MA in Sámi language and Culture, Oulu University. Education, Oulu University.

- Male, 25-29 years old, Oulu (from Rovaniemi), education: psychiatric nurse, Oulu university hospital.

- Female, 18-24 years old, Kautokeino (from Alta), duodji apprentice, student at Sámi Up per Secondary and Reindeer Husbandry School.

- Female, 18-24 years old, Tromsø, in between educational programmes, has studied Sámi language in Kautokeino.

- Female, 25-29 years old, Trondheim (from Kautokeino), Student, geography, Trondheim University. herding apprentice, student at Sámi Upper Secondary and Reindeer Husbandry School.

- Male, 18-24 years old, Jokkmokk, student, construction at the Sámi Education Centre.

Male, 18-24 years old, Jokkmokk (from Stockholm), in between educational programmes, focus on theatre at upper secondary school.

Male, 18-24 years old, Jokkmokk, reindeer herder, focus on construction at upper secondary school.

Female, 18-24 years old, Jokkmokk, reindeer herder. whereas in Finland a representative from the Sám

- Female, 25-29 years old, Inari, education: MA in

- Male, 18-24 years old, Kautokeino, reindeer 
Sámi educational institutions: A total of seven interviews were conducted with representatives from Sámi educational institutions: three from higher education (Sámi University of Applied Sciences and Umeå University), one from vocational education (Sámi Education Centre in Jokkmokk), and three from Sámi upper secondary schools (based in Kautokeino and Jokkmokk). It has not been possible to obtain interviews with representatives from education institutions in Finland. The Sámi Education Institute and the Sámi Upper Secondary School in Utsjoki both declined to par-

ticipate in this study. We have compensated for this through desk research and through information provided by the other interviewees in Finmawho also have knowledge of the Sami education institutions. institutions.

Johan Ailo Kalstad, Director, Sámi University of Applied Sciences.

- Liv Inger Somby, Associate Professor, Sámi

University of Applied Sciences,

- Ellen Inga Hætta, Principal, Sámi Upper Secondary and Reindeer Husbandry School, Kautokeino.

- Anna-Lill Drugge, Associate Professor, Umeå University.

- Britt-Inger Tuorda, Principal, Sámi Education Centre, Jokkmokk.

- Eva Öhlund Wästerberg, Acting Principal,

Upper Secondary School of Lapland,

- Jan-Erik Kuoljok, responsible for the Sámi programme, Upper Secondary School of Lapland, Jokkmokk. 


\section{$\mathbb{1}$ Nordregio}

P.O. Box 1658

SE-111 86 Stockholm, Sweden

nordregio@nordregio.org

www.nordregio.org

www.norden.org

ISBN 978-91-87295-93-5 (PDF)

ISSN 1403-2503

DOI: http://doi.org/10.6027/R2020:5.1403-2503 